\title{
LEGAL REGULATION OF ACTIVITY OF SELF-EMPLOYED CITIZENS IN THE RUSSIAN FEDERATION
}

\author{
Aleksandr N. Shpagonov ${ }^{1}$ \\ Regina R. Dolotina ${ }^{2}$
}

\begin{abstract}
This paper is devoted to the analysis of legal regulation issues concerning self-employed citizens in the Russian Federation as part of an experiment in certain regions of Russia on the legalization of self-employed people's activities. The way out of the shadow of the self-employed people is one of the most discussed issues not only in Russia, but also in many countries of the world. The unwillingness to officially register their activities is explained, first of all, by the fact that the payment of taxes, as a rule, is incommensurable with the income of the self-employed people. At the same time, without registering their business, selfemployed citizens are left without their social protection from the state, and without the opportunity to receive development loans, etc. The state should encourage self-employment people, as it
\end{abstract}

contributes to solving the problem of unemployment. In the EU and the USA, the self-employed population provides business, social, real estate, intermediary services, as well as provides counselling, advertising, retail, franchising and other activities (over 400 types of activities). At the same time, a self-employed citizen can provide paid services to various organizations on a certain range of issues, demonstrating their professional qualities, either with the prospect of possible employment in these organizations as a specialist, consultant or contractor, or remaining a specialist in a free profession [1]. For most countries, the issue of how to legitimize the activities of the selfemployment people is relevant, so that on the one hand, the budget is replenished, and on the other, social guarantees are established [2]. In the

\footnotetext{
${ }^{1}$ Kazan Federal University. Kremliovskaya str, 18, 420008, Kazan, Russian Federation. e-mail (email address for communication): shpagonovan@gmail.com. Tel. (contact phone): 89053178148

${ }^{2}$ Russian State University of Justice (Kazan branch). Azinskaiya str, 7 A, 420088, Kazan, Russian Federation.
} 
course of the study of the stated problems, the authors come to the conclusion that today the Russian Federation needs to build a social security system for self-employed citizens. At the same time, the tax on professional income should remain unchanged.

Keywords: self-employed citizens, state, professional income tax, social security.

\section{Introduction}

Self-employed people are individual entrepreneurs, heads and members of peasant (farm) enterprises, lawyers, arbitration managers, notaries and other private practitioners who are not individual entrepreneurs. From January 1, 2019, this category includes persons applying the special tax regime "Professional income tax" (paying professional tax).

The paper will discuss current legal regulation issues concerning activities of only those self-employed citizens who pay professional tax in connection with the adoption of Federal Law dated 11.28.2018 No. 422-FZ [3] (hereinafter, Law No. 422-FZ).

\section{Methods}

The main methods that were used during the writing of this work are: a comparative legal method, a complex analysis method, an interpretation method, a sociological method, a system analysis method and an intersectoral approach.

\section{Results and discussion}

There is no legal definition of a self-employment citizen in the Russian legislation.

Self-employment is a form of atypical employment. The main task of the state today is to bring self-employed citizens out of the shadows. This should be facilitated by the experiment, which since January 1, 2019 is held in some constituent entities of the Russian Federation - in the city of Moscow, in the Moscow and Kaluga regions, as well as in Republic of Tatarstan.

The problem of identifying and legalizing self-employed citizens is characteristic not only of Russia, but also of most foreign countries [4].

The legalization of the activities of self-employed citizens in Russia within the framework of the above experiment suggests the following. 
Self-employed citizens without registration as an individual entrepreneur can apply a special tax regime, i.e professional income tax (PIT). In particular, citizens who provide services to individuals for personal, household and other similar needs can switch to this special regime.

Conditions under which a person may apply this special tax regime:

- Income of a self-employed person should be from the sale of goods (work, services, property rights), with the exception of income specified in part 2 of article 5 of the Law No. 422-FZ;

- Income of a self-employed person during a calendar year should not exceed 2.4 million roubles;

- It is necessary to be registered with the tax authority as a taxpayer (paragraph 6, clause 2, article 18 of the Tax Code of the Russian Federation; p. 1 article 1, parts 1, 6, 7 of Art. 2, Art. 4, part 1 , article 5 , part 2 , article 6 , article 16 of the Law No. 422-FZ dated November 27, 2018).

The use of a special tax regime, i.e. a tax on professional income, will exempt certain categories of citizens (taxi drivers, freelancers, plumbers, electricians, artisans, bloggers, etc.) from paying personal income tax (PIT).

In accordance with Article 10 of Law No. 422-FZ, the tax rate on professional income of self-employed persons depends on whom the service is provided for, and amounts to: $4 \%$ in relation to income received by taxpayers from the sale of goods (work, services, property rights) to individuals; $6 \%$ in relation to income received by taxpayers from the sale of goods (works, services, property rights) to individual entrepreneurs for use in entrepreneurial activities and legal entities.

The undoubted advantages of this experiment are:

- "Painless" legalization of selfemployed citizens;

- A simplified tax registration system, in particular, through the use of the My Tax mobile application;

- Low tax rate;

- The absence of the need to submit a tax declaration to tax authorities;

- Lack of taxes in the absence of profit,

- There is no need for a current account - a self-employed person can 
accept money in cash or in non-cash form on bank card,

- Checks are issued in electronic form via the My Tax mobile application, - Until December 31, 2028, no changes will be made to Law No. 422$\mathrm{FZ}$ regarding the increase in tax rates and (or) the reduction of the maximum income,

- Tax deduction in the amount of 10,000 roubles.

With all the positive aspects of the experiment, one should not forget about the social vulnerability of selfemployed citizens, and about a decrease in social guarantees.

In the first two months of 2019 , more than 33,000 people were registered as self-employed [5]. However, there are not so many people who want to legalize their activities. This is due, in our opinion, to the lack of a system of social guarantees.

Currently, the activities of selfemployed citizens are not regulated by labour legislation. Accordingly, selfemployed persons will not be able to rely on various types of guarantees provided for workers.

When paying a professional tax, the self-employed will not be able to rely on certain types of benefits, such as temporary disability benefits, maternity benefits and others, provided for working citizens.

Therefore, in our opinion, it is necessary to supplement Part 3, Art. 2 of the Federal Law dated December 29, 2006 No. 255-FZ “On Compulsory Social Insurance for the Case of Temporary Disability and in Connection with Maternity", including selfemployed citizens as subjects entitled to voluntarily enter into relations on compulsory social insurance for the case of temporary disability and in connection with maternity.

Persons paying professional tax are also not payers of insurance contributions for compulsory pension insurance (Art. 419 of the Tax Code of the Russian Federation). The pension rights of these persons arise only in the event of entering into voluntary legal relations on compulsory pension insurance and payment of insurance premiums in accordance with Art. 29 of the Federal Law dated December 15, 2001 No. 167-FZ “On Compulsory Pension Insurance in the Russian Federation". 
Voluntary

pension

contributions allow an insurance pension and seniority to create. The amount of voluntary contributions to the Pension Fund of the Russian Federation in 2019 is 29,354 roubles for a full year, in 2020 - 32,448 roubles for a full year. The amount of pension contributions is quite impressive for the self-employed citizens. Self-employed citizens will most likely not voluntarily enter into these relations.

Turning to the experience of the United States, we note that selfemployed persons, as well as in Canada, [6] pay income tax (from $10 \%$ to $39.6 \%$, depending on the amount of profit), as well as "self-employment tax", which includes compulsory insurance contributions for social and health insurance (15.3\% of profit) [7].

In the UK, national selfemployed insurance premiums are a fixed amount of GBP 3 per week. It is charged only if the annual profit of "selfemployed persons" is 6365 pounds or more. National insurance premiums are levied only if the annual profit is 8632 pounds or more. They accrue at the rate of nine per cent of profit between GBP 8,632 and 50,000 and two per cent of profit which is more than GBP 50,000 [8].

The experience of Kazakhstan is interesting, where, in order to simplify the registration and legalization of the activities of informally employed people, relevant changes to the law have been prepared [9]. Namely, a new legal regime has been developed here, the Unified Comprehensive Payment (UCP), for payers of which lower tax and social payment rates are determined, the payment of which will allow registering and participating in the system of compulsory medical and social insurance, as well as pension benefits. The size of the UCP is $\$ 6.5$ per month for the urban population or $\$ 3.25$ per month for the rural population. The following payments are included in a single aggregate payment:

- $40 \%$ - compulsory social health insurance;

- 30\% - pension contributions;

- $20 \%$ - compulsory social insurance;

- 10\% - tax (budget revenue) $[10,11,12,13,14]$.

The experience of Kazakhstan can be adopted in the Russian Federation in view of the fact that, despite the low 
tax rates, the state has provided a complete social security system for the self-employed population.

\section{Summary}

The authors believe that the social security system for the selfemployed population in Russia should become mandatory. Thus, the tax on professional income must include the appropriate insurance contributions for social, medical and pension benefits. This will allow the Pension Fund of the Russian Federation, the Compulsory Medical Insurance Funds of the Russian Federation, and the Social Insurance Fund of the Russian Federation to replenish their budget, and the selfemployed - to have minimal, but reliable social guarantees: appropriate social benefits, medical care and treatment, as well as the right to old-age insurance pension.

\section{Conclusion}

The issues we have outlined in the legal regulation of the activities of self-employed persons in the Russian Federation are extremely relevant.

Come out of the shadow for a self-employed population is a great responsibility for the state. The costs of social payments to the Pension Fund and to compulsory health insurance and social insurance funds will increase significantly. But, only by competently building a social security system for selfemployed citizens, and without increasing tax rates, the state will be able to fully fulfil its social obligations to citizens.

\section{Acknowledgments}

The work is performed according to the Russian Government Program of Competitive Growth of Kazan Federal University.

\section{References}

Bondarenko V.A. Self-employment development in the countries of the European Union and the USA. URL: http://www.vneshmarket.ru/content/doc ument_r_A4F92072-2395-4116-96E5EE76169118C7.html.

See: Krylova E.G. Features of economic regulation regarding entrepreneurial activity of self-employed people in Russia and abroad // Lawyer. - 2017. - N 6. - Pp. $11-15$. 
See: Herb J. Schuetze. Profiles of Tax Non-Compliance among the SelfEmployed in Canada // Canadian Public Policy / Analyze de Politiques. - 2002. N 2. - Pp. 219 - 238.

Federal Law No. 422-FZ dated November 27, 2018 "On the experiment to establish a special tax regime "Professional income tax" in the city of federal significance Moscow, and also Moscow and Kaluga regions, as well as in the Republic of Tatarstan (Tatarstan)" / / Russian newspaper. - 2018. -- N 270.

URL: https://www.vedomosti.ru/

URL:

https://www.canada.ca/en/services/bene fits/publicpensions/cpp/cpp-

enhancement.html

US Federal Government Social Security Administration Information Letter of 2019 , URL: https://www.ssa.gov/pubs/EN-0510022.pdf

URL: $\quad$ https://www.gov.uk/selfemployed-national-insurance-rates
Draft law of the Republic of Kazakhstan "On amendments and additions to some legislative acts of the Republic of Kazakhstan on the formalization of employment" // URL: http://www.parlam.kz/ru/mazhilis/itrece ived

Khasenov M.Kh. Legal regulation of the activities of the self-employed population // Labour law in Russia and abroad. - 2019. - N 1. - S. 23 - 24.

Rezaei, M., \& Nemati, K. (2017). The Impact of Purchase Intent, Word of Mouth Advertising and Skill Domain of Seller on Quality of Customer Relationship to Sale Life and Savings Insurance Policies (Case Study: Dana Insurance Co., Bushehr Province). Dutch Journal of Finance and Management, 1(2),

43.

https://doi.org/10.29333/djfm/5819

Torquato, M., Araujo, J., Umesh, I. M., \& Maciel, P. (2018). SWARE: A Methodology for Software Aging and Rejuvenation Experiments. Journal of Information Systems Engineering \& Management, 3(2), 15. 
Peranginangin, S. A., Saragih, S., \&

Siagian, P. (2019). Development of

Learning Materials through PBL with

Karo Culture Context to Improve

Students' Problem Solving Ability and

Self-Efficacy. International Electronic

Journal of Mathematics Education,

$14(2)$,

265-274.

https://doi.org/10.29333/iejme/5713

Feizuldayeva, S., Ybyraimzhanov, K., Mailybaeva, G., Ishanov, P., Beisenbaeva, A., \& Feizuldayeva, S. (2018). Vocational training of future elementary school teacher by means of realization of inter-subject continuity. Opción, 34(85-2), 479-516 